NBER WORKING PAPER SERIES

\title{
MAKING IT IN AMERICA: SOCIAL MOBILITY IN THE IMMIGRANT POPULATION
}

\author{
George J. Borjas \\ Working Paper 12088 \\ http://www.nber.org/papers/w12088 \\ NATIONAL BUREAU OF ECONOMIC RESEARCH \\ 1050 Massachusetts Avenue \\ Cambridge, MA 02138 \\ March 2006
}

Robert W. Scrivner Professor of Economics and Social Policy, John F. Kennedy School of Government, Harvard University; and Research Associate, National Bureau of Economic Research. I am grateful to Min Zhou for providing very helpful comments on an earlier draft of this paper. The views expressed herein are those of the author(s) and do not necessarily reflect the views of the National Bureau of Economic Research.

(C)2006 by George J. Borjas. All rights reserved. Short sections of text, not to exceed two paragraphs, may be quoted without explicit permission provided that full credit, including (C) notice, is given to the source. 
Making it in America: Social Mobility in the Immigrant Population

George J. Borjas

NBER Working Paper No. 12088

March 2006

JEL No. J61

\begin{abstract}
The ultimate impact of immigration on the United States obviously depends not only on the economic, social, political, and cultural shifts that take place during the life cycle of the immigrant population, but also on the adjustment process experienced by the immigrant household across generations. This paper documents the evidence on social mobility in the immigrant population and summarizes some of the lessons implied by the evidence. There is significant economic "catching up" between the first and second generations, with the relative wage of the second generation being, on average, about 5 to 10 percent higher than that of the first generation. At the same time, there is a strong positive correlation between the socioeconomic outcomes experienced by ethnic groups in the immigrant generation and the outcomes experienced by their children, and a weaker correlation between the immigrants and their grandchildren. In rough terms, about half of the differences in relative economic status across ethnic groups observed in one generation persist into the next. As a result, the very large ethnic differences in economic status that characterize the current immigrant population will likely dominate discussions of American social policy for much of the 21 st century.
\end{abstract}

\author{
George J. Borjas \\ Kennedy School of Government \\ Harvard University \\ 79 JFK Street \\ Cambridge, MA 02138 \\ and NBER \\ gborjas@harvard.edu
}




\section{MAKING IT IN AMERICA: SOCIAL MOBILITY IN THE IMMIGRANT POPULATION George J. Borjas*}

\section{Introduction}

The ultimate impact of immigration on the United States obviously depends not only on the economic, social, political, and cultural shifts that take place during the life cycle of the immigrant population, but also on the adjustment process experienced by the immigrant household across generations. Because of the resurgence of large-scale immigration in recent decades, which raised the foreign-born share of the U.S. population from 4.7 percent in 1970 to 12.7 percent in 2003, the population share of second generation persons (i.e., of persons born in the United States with at least one foreign-born parent) is expected to grow rapidly in the next few decades, from 10.5 percent in 2004 to nearly 14 percent by 2050 . Moreover, the grandchildren of current immigrants will make up an additional 9 percent of the population by mid-century. ${ }^{1}$

The traditional view of the social mobility experienced by immigrant households across generations is vividly encapsulated by the melting pot metaphor: Immigrants are molded from a collection of diverse national origin groups into a homogeneous native population in a relatively short time, perhaps two generations. Although many analysts have questioned the relevance of the melting pot hypothesis for understanding the experience of many ethnic groups in the United States, the metaphor seems to have a magnetic and intuitive appeal that often confounds the

\footnotetext{
* Robert W. Scrivner Professor of Economics and Social Policy, John F. Kennedy School of Government, Harvard University; and Research Associate, National Bureau of Economic Research. I am grateful to Min Zhou for providing very helpful comments on an earlier draft of this paper.

1 Barry Edmonston and Jeffrey S. Passel, "Immigration and Immigrant Generations in Population Projections," International Journal of Forecasting 8, no. 3 (1992): 459-476.
} 
detractors. $^{2}$ As a result, the "assimilationist" perspective has long dominated the thinking of many observers of the immigrant experience.

Ironically, and from a purely economic perspective, it is not clear that the United States would be better off if the melting pot operated at breakneck speed, quickly assimilating the new immigrants and churning them out as clones of native-born workers. After all, the productivity gains from immigration are maximized when the immigrant population differs most from the native population and immigrants have skills that the native workforce lacks — or in the commonly used phraseology, when "immigrants do jobs that natives do not want to do." As a result, the productivity gains from immigration would be larger if the United States pursued policies that hampered and delayed the assimilation of immigrants. If the melting pot were to operate smoothly, the only way that the country could replenish the productivity gains from immigration would be to admit more and more immigrants.

Of course, this perspective is much too narrow and misses the point. Most available estimates suggest that the net productivity gains from immigration are quite small even in the

2 Classic expositions of the melting pot hypothesis are given by Robert Park, Race and Culture (Glencoe, IL: Free Press, 1975); and Milton Gordon, Assimilation and American Life (New York: Oxford University Press, 1964). The revisionist literature that questions the empirical validity of the hypothesis include the studies of Nathan Glazer and Daniel P. Moynihan, Beyond the Melting Pot: The Negroes, Puerto Ricans, Jews, Italians, and Irish of New York City (Cambridge, MA: MIT Press, 1963); Stanley Lieberson and Mary C. Waters, From Many Strands: Ethnic and Racial Groups in Contemporary America (New York: Russell Sage, 1988); Joel Perlmann, Ethnic Differences: Schooling and Social Structure Among the Irish, Italians, Jews, and Blacks in an American City, 18801935 (New York: Cambridge University Press, 1988); and Alejandro Portes and Min Zhou, "The New Second Generation: Segmented Assimilation and Its Variants," The Annals of the American Academy of Political and Social Science 530 (1993): 74 96. A good survey of the competing hypotheses is given by Min Zhou, "Segmented Assimilation: Issues, Controversies, and Recent Research on the New Second Generation," International Migration Review 31, no. 4 (1997): 825-858. 
first generation, when the immigrants are most different from native workers. ${ }^{3}$ Moreover, the economic, social, and political consequences of delaying assimilation could be disastrous. The ethnic conflicts in many regions of the modern world, for instance, often originated centuries ago, and their consequences still fester. One does not have to be a very astute observer of the human condition to learn that it pays to have a cohesive social fabric. Therefore, it is probably in the national interest of the United States to pursue policies that spur substantial intergenerational progress by immigrant households, and that reduce the importance of ethnicity in determining socioeconomic outcomes in future generations.

This paper summarizes the evidence on social mobility in the immigrant population and draws out some of the lessons implied by the evidence. The available data suggests that there is significant economic "catching up" between the first and second generations, with the relative wage of the second generation being, on average, about 5 to 10 percent higher than that of the first generation. At the same time, the evidence indicates that there is a strong positive correlation between the socioeconomic outcomes experienced by ethnic groups in the immigrant generation and the outcomes experienced by their children, and a weaker correlation between the immigrants and their grandchildren. In rough terms, about half of the differences in relative economic status across ethnic groups observed in one generation persist into the next. As a result, the very large ethnic differences in economic status that characterize the current

3 George J. Borjas, “The Economic Benefits from Immigration," Journal of Economic Perspectives 9, no. 2 (1995): 3-22; and Donald R. Davis and David E. Weinstein, "Technological Superiority and the Losses from Migration," Working Paper 8971 (Cambridge, Mass.: National Bureau of Economic Research, 2002). 
immigrant population will likely dominate American society_and discussions of American social policy - for much of the $21^{\text {st }}$ century.

\section{An Economic Perspective on Social Mobility}

From a broad perspective, the process of social mobility in immigrant households encompasses a wide variety of related phenomena, including the cultural adaptation that immigrants and their children make to their new environment, the adoption of social norms and attitudes that may differ greatly from those that the immigrant generation brought from the sending countries, and the accumulation of human capital investments, including educational attainment, language skills and geographic resettlement, that improve the immigrant's economic status in the receiving country. The discussion in this paper focuses exclusively on this economic aspects of social mobility - the rate at which the economic status of the immigrant household improves across generations. Hence it provides a very restrictive picture of the intergenerational changes that immigrant households inevitably experience in the United States.

Despite this narrow focus, however, there is an important link between the economic notion of social mobility stressed here and the cultural issues that are traditionally emphasized in the immigration debate in the United States and many other receiving countries. In order to experience economic improvement, an immigrant will often have to acquire skills that are valued by American employers, such as learning the English language, adopting the norms of the American work place, and moving to economically vibrant areas that may lie far beyond the borders of the ethnic enclave. Each of these decisions helps to weaken the link between the immigrant's foreign past and his or her American future. 
Many immigrants, therefore, face an important tradeoff: In order to achieve economic progress they may have to discard some of the attributes, habits, and cultural characteristics that can hamper the chances of success in the American economy, and pick up the ones that enhance those chances. Put differently, economic and non-economic forms of social mobility may often complement each other: there will be more mobility of one type when there is more mobility of the other.

The existing literature on immigrant economic performance has provided two insights that now serve as "stylized facts" in the immigration debate. First, the typical immigrant worker in the United States suffers a sizable earnings disadvantage (relative to native-born workers) upon arrival, and it is unlikely that this disadvantage disappears during the immigrant's working life. Second, there is a great deal of dispersion in socioeconomic status and earnings across the many national origin groups that make up the first generation. ${ }^{4}$

Even within the boundaries provided by the narrow definition of social mobility used in this paper, any study of intergenerational economic progress in immigrant households needs to examine two related, but distinct, phenomena. First, to what extent does the economic disadvantage experienced by immigrants narrow across generations? Put differently, do the children (or grandchildren) of immigrants "catch up" to the average economic status of the baseline population. It seems reasonable to suspect that the second-generation enjoys a "head start" in their earnings capacity that is not experienced by any other generation. After all, second-generation Americans are typically the first members of the immigrant household to graduate from American schools, the first to benefit from having English as a native tongue, and

4 George J. Borjas, “The Economics of Immigration,” Journal of Economic Literature 32, no. 4 (1994): 1667-1717; and David Card, "Is the New Immigration Really So Bad?" Economic Journal 115, no. 507 (November 2005): F300-F323. 
the first to know about the internal workings of the U.S. labor market prior to getting their first job.

Second, it is well known that the relation between the earnings of parents and children, regardless of whether the parents are foreign- or native-born, is driven by a phenomenon known as regression towards the mean. Even though the children of highly successful parents are themselves likely to be successful, it is unlikely that the children will be as successful as their parents. The economic performance of these children will probably revert somewhat towards the lower population average. Similarly, even though the children of low-skill parents are themselves likely to be low-skill, it is unlikely that the children will be as unskilled as the parents, and again there is a reversion towards the higher population average. Regression towards the mean acts like a double-sided magnet: it pulls the economic status of the children in outlying groups towards the mean of the population, regardless of where the parents start out.

This phenomenon occurs because parental skills and family background are not the only factors that influence the intergenerational transmission of skills. Many other unknown and random factors also enter the process, including luck and imperfect genetic transmission of ability, motivation, and drive. These extraneous factors imply that the children of parents who reside at either tail of the wage distribution will probably lie closer to the middle of that distribution.

The concept of regression towards the mean plays a crucial role in understanding the process of social mobility in the immigrant population. Some ethnic groups enter the United States doing very well in the labor market, while other groups perform very poorly. Part of these ethnic differences will likely be transmitted to their offspring. The melting pot metaphor, in effect, argues that ethnicity is not "sticky". Ethnic differences disappear in a relatively short time 
and all the groups eventually become indistinguishable from each other. The conjecture of a quick-acting melting pot, therefore, is an empirical statement about the extent of regression towards the mean in the economic status of different ethnic groups. If regression towards the mean is an important phenomenon, the differences observed among ethnic groups in the first generation will not last long, and an immigrant's ethnic background should have little influence on the economic outcomes of his descendants. ${ }^{5}$

\section{The Economic Performance of the Children of Immigrants}

It is widely perceived that, on average, the socioeconomic performance of the children of immigrants far surpasses that of their parents. This perception originated in the early studies of Barry Chiswick and Geoffrey Carliner that compared the earnings of various generations of workers in the United States at a particular point in time, such as the 1970 decennial Census. ${ }^{6}$ Table 1 summarizes the available evidence for three such cross-sections: the 1940 Census, the 1970 Census, and the pooled 1994-2003 Current Population Surveys (which, for convenience, I will refer to as the 2000 cross-section). ${ }^{7}$

\footnotetext{
5 Note that the second-generation may experience an increase in their earnings capacity-relative to that of the first generation - even if there were no regression towards the mean (each second-generation national origin group would then simply earn $x$ percent more than the corresponding group in the immigrant generation, but there would be no narrowing of ethnic wage differentials). Although these two sources of economic mobility are sometimes confused in the literature, they capture different phenomena.

6 Barry R. Chiswick, "Sons of Immigrants: Are They at an Earnings Disadvantage?" American Economic Review 67, no. 1 (1977): 376-380; and Geoffrey Carliner, "Wages, Earnings, and Hours of First, Second and Third Generation American Males," Economic Inquiry 18, no. 1 (1980): 87-102.

7 The data sources are the 1940 and 1970 Integrated Public Use Microdata Series (IPUMS) of the decennial U.S. Census, as well as the pooled 1994-2003 IPUMS-CPS files of the March Current Population Surveys.
} 
Each of these cross-section data files allows the precise identification of two generations of Americans: the immigrant generation (i.e., persons born abroad) and the second generation (i.e., persons born in the United States who have at least one parent born abroad). The generation of the remaining persons in the sample (i.e., of persons who have American-born parents and were themselves born in the United States) cannot be determined exactly, but they are typically referred to as "third-generation" Americans. It is worth noting, however, that this residual group of third-generation workers contains individuals who are both grandchildren of immigrants as well as descendants of the Mayflower Pilgrims.

For each of the available data cross-sections, Table 1 reports the (age-adjusted) log weekly wage of first- and second-generation workers relative to that of the baseline third generation. ${ }^{8}$ In 1970, for example, immigrant men earned about 1.4 percent than men in the third-generation, while second-generation working men earned 14.6 percent more than the baseline workforce. Even though trends in the relative wage of working women are influenced by the selection biases associated with rising female labor force participation, the table reveals exactly the same intergenerational pattern in relative wages for women. The typical working immigrant woman earned 6.8 percent more than women in the third generation, while the typical second generation working woman earned about 10.1 percent more. In short, second-generation workers in 1970 earned more than both the immigrants and than the subsequent generations.

\footnotetext{
8 The log wage differential is calculated in the sample of workers aged 18-64 who do not reside in group quarters, work in the civilian sector, are not enrolled in school, and report a valid measure of earnings for the calendar year prior to the survey. The adjusted wage differences were calculated by estimating a log weekly earnings regression model that includes dummy variables indicating the worker's generation as well as a vector of dummy variables indicating the worker's socioeconomic characteristics (such as age and education). The regressions using the pooled Current Population Surveys also include a vector of dummy variables indicating the year of the survey.
} 
In fact, Table 1 reveals this exact empirical pattern for every single cross-section of data. In 1940, for example, second-generation working men earned 17.8 percent more than the baseline third-generation, while immigrants earned only 5.8 percent more. In 2000, secondgeneration working men earned 6.3 percent more than the baseline third-generation, while immigrants earned 19.7 percent less.

The wage superiority of the second generation workforce in each cross-section snapshot seems to imply —and has been interpreted as implying — that second-generation Americans earn more than both their parents and their children. A common story used to explain this inference is that the children of immigrants are "hungry" and have the drive and ambition that ensures economic success in the U.S. labor market—and that this hunger is lost once the immigrant household becomes fully Americanized by the third generation. If this interpretation were correct, the policy concern over the relatively low skill level of the immigrants who have arrived in the past three decades may be misplaced. If historical patterns were to hold in the future, the children of these immigrants will outperform not only their parents but the rest of the workforce as well in only a few decades.

It turns out, however, that the evidence summarized in Table 1 does not necessarily justify this inference. After all, the family ties among the three generations identifiable in any cross-section of data are very tenuous. It is biologically impossible for most second-generation workers enumerated in a particular cross-section to be the direct descendants of the immigrants enumerated at the same time. For instance, working-age immigrants enumerated in 2000 (most of whom arrived in the 1980s and 1990s) typically cannot have American-born children who are also of working age. Second-generation Americans of working age can only be the descendants of immigrants who have been in the country for at least two or three decades. Put differently, 
most of the second-generation workers enumerated in 2000 are unlikely to be the children of the immigrant workers enumerated at the same time. Because there are skill differences across immigrant cohorts, and because some of these differences could easily be transmitted to their children, the wage gap between first- and second-generation workers in a cross-section does not correctly portray the social mobility that occurs across generations.

In short, the fact that second-generation workers earn more than other workers at a particular point in time does not necessarily imply that second generation workers earn more than either their parents or their children. To calculate the improvement in economic status between the first and second generations, one must link the economic performance of parents and children, rather than compare the economic performance of workers belonging to different generations at a point in time.

It is possible to conduct the correct intergenerational comparison by tracking the immigrant population over time..$^{9}$ For instance, the 1970 Census provides information on the economic performance of the immigrants present in the United States at that time. Many of these immigrants are, in fact, the parents of the second-generation workers enumerated in the 2000 cross-section. Similarly, the 1940 Census provides information on the economic performance of immigrants in 1940. These immigrants, in turn, are probably the parents of the second-generation workers enumerated by the 1970 Census. It is only by comparing the economic performance of immigrant workers in 1940 with the economic performance of second-generation workers in 1970 - or the economic performance of immigrants workers in 1970 with that of the second-

9 George J. Borjas, “The Intergenerational Mobility of Immigrants," Journal of Labor Economics 11, no. 1, Part 1 (1993): 113-135. 
generation in 2000 - that we can correctly determine the economic progress experienced by the children of immigrants.

To illustrate, consider again the wage information summarized in Table 1. If we (incorrectly) used only the information provided by the 2000 cross-section, we would conclude that since second generation workers earn 6.3 percent more than the baseline third generation and first-generation workers earn 19.7 percent less than the baseline, second-generation workers earn 26.0 percent more than first-generation workers. A correct calculation of the secondgeneration improvement, however, reveals much less intergenerational improvement. After all, the typical immigrant in 1970 earned 1.4 percent more than the typical third-generation worker. And the typical second-generation worker in 2000 (who is presumably the descendant of the immigrants enumerated in 1970) earns 6.3 percent more than the baseline. In short, the true intergenerational growth in relative wages was only on the order of 5 percent - rather than the 26 percent implied by the intergenerational wage differentials observed in 2000 .

Similarly, the 1970 Census seems to imply that the children of immigrants earn 13.2 percent more than their parents (or 14.6 percent minus 1.4 percent). But the economic status of the parents of these second-generation workers can only be observed in the 1940 Census, where the immigrants had a relative wage advantage of 5.8 percent. The intergenerational wage improvement between 1940 and 1970 is then on the order of 8.8 percent (or .146 - .058). Again, immigrant households experienced less wage growth across generations than would be implied by looking at the intergenerational wage differentials in a single cross-section. Note, however, that the 5 to 10 percent intergenerational wage growth between the first and second generations still represents a substantial improvement in economic opportunities. 
The bottom panel of the table reports the wage differentials among the various generations after the data are adjusted for differences in educational attainment across workers. The adjusted wage differentials (for both working men and women) reveal that much of the intergenerational progress found in the "raw" data disappears once the data are adjusted for differences in educational attainment. Put differently, much of the intergenerational progress observed between the first and second generations (which leads to the 5 to 10 percent wage increase in the second generation) can be explained by the changes in educational attainment that occur between these two generations, as the native-born children of immigrants go through the American education system.

Finally, the evidence summarized in Table 1 reveals a second potentially important empirical pattern. In particular, note that the age-adjusted relative wage of immigrants has declined steadily since 1940. In 1940, the typical immigrant working man earned 5.8 percent more than workers in the third generation; by 1970, this economic advantage had fallen to +1.4 percent; and by 2000 the slim economic advantage had become a sizable wage disadvantage of 19.7 percent. Although this decline in the relative economic status of the immigrant workforce has been well documented in the literature, the data in Table 1 also show a concurrent (and much less studied) decline in the relative wage of the second generation workforce. In 1940, the typical second generation working man earned 17.8 percent more than workers in the baseline thirdgeneration; by 1970, the wage advantage had fallen to 14.6 percent, and by 2000 it had fallen to 6.3 percent. In short, the relative economic status of second-generation workers has been falling over time - just like that of the foreign-born workforce.

Put differently, the data clearly reveal that the second generation workers enumerated in 2000 (whose parents made up the immigrant workforce in 1970) have a lower economic status 
than the second generation workers enumerated in 1970 (whose parents made up the immigrant workforce in 1940). If these historical trends were to continue, the extrapolation of the data over the next few decades can easily lead to a somewhat pessimistic forecast for the economic performance of the children of the current (i.e., circa 2000) wave of immigrants. These immigrants now have a substantial wage disadvantage of 19.7 percent. If the intergenerational jump in relative earnings between the first and second generation is between 5 and 10 percent, the children of the current immigrant workforce will experience a 10 percent wage disadvantage circa 2030. This remarkable turnaround in the economic status of the second generation highlights an important insight provided by the historical experience: the secular trend in the relative economic performance of the second generation workforce tracks that of the first generation, but with a generational lag. ${ }^{10}$

\section{The Persistence of Ethnic Wage Differentials}

There is a lot of variation in socioeconomic status among ethnic groups both in the first and second generations. Some national origin groups, typically those originating in advanced economies, do quite well in the U.S. labor market, while other national origin groups, typically originating in poorer countries, fare much worse. Table 2 shows some of this variation for a select number of national origin groups. ${ }^{11}$ In 1970 for instance, immigrants from Canada earned 18.5 percent more than the typical worker in the baseline third generation, while immigrants

\footnotetext{
10 See also Joel Perlmann and Roger Waldinger, "Second Generation Decline? Children of Immigrants, Past and Present—A Reconsideration," International Migration Review 31, no. 4 (1997): 893-922.

11 The ethnic background of second-generation Americans in the calculations presented in this section is determined by the mother's country of birth (unless only the father is foreign-born, in which case it is determined from the father's country of birth).
} 
from Mexico earned 31.6 percent less. By 2000, second-generation workers from Canada earned 16.8 percent more than the typical third-generation worker, while second-generation workers from Mexico earned 14.7 percent less.

To determine how much of the ethnic differences in relative economic status that exist among immigrants persist into the second generation, some studies estimate statistical models that relate the relative wage of a second generation national origin group to the relative wage of their first-generation counterpart. ${ }^{12}$ The statistical analysis, of course, accounts for the fact that first and second generation workers observed in a single cross-section of data have little biological connection with each other, so the statistical models link the relative earnings of second generation workers at a particular point in time (e.g., the 2000 cross-section) to the earnings of first-generation workers a few decades past (e.g., the 1970 Census).

Before summarizing the statistical evidence, it is insightful to illustrate the nature of the empirical exercise. Figure 1 shows the intergenerational link for male workers belonging to a large number of national origin groups in the $1970-2000$ period..$^{13}$ The horizontal axis gives the age-adjusted relative wage of working men in the immigrant generation. These data are obtained from the 1970 Census. The vertical axis gives the age-adjusted relative wage of the working men in the second generation, and these data are obtained from the 2000 cross-section. There is an obviously strong and positive correlation between the average skills of workers in the two

12 George J. Borjas, “The Intergenerational Mobility of Immigrants," Journal of Labor Economics 11, no. 1, part 1 (1993): 113-135; David Card, John DiNardo, and Eugena Estes, "The More Things Change: Immigrants and the Children of Immigrants in the 1940s, the 1970s, and the 1990s," in Issues in the Economics of Immigration, edited by George J. Borjas (Chicago: University of Chicago Press, 2000), pp. 227-270.

13 The figure provides information for 61 national origin groups. Each group satisfies the sample restriction that there were at least 20 observations in both the 1970 and 2000 cross-sections to calculate the wage of the ethnic group in each respective generation. 
generations; the national origin groups that fared economically well in the first generation also fared well in the second.

The upward-sloping regression line illustrated in Figure 1 summarizes the statistical relationship that links the relative wages of particular national origin groups across the two generations. The slope of this regression line is often called the intergenerational correlation in relative wages and measures the extent of regression towards the mean across generations.

If the regression line were relatively flat, it would indicate that there is little connection between the average skills of the ethnic groups in the second generation and the average skills of the immigrant groups. Put differently, all second-generation groups would have relatively similar wages regardless of the economic performance of their parents. In this case, the intergenerational correlation would be near zero, and there would be complete regression towards the mean. If the regression line were relatively steep, there would then be a substantial link between relative wages in the first and second generations. If the intergenerational correlation were equal to one, for example, there would be a perfect correlation between the relative wages of the two generations and the regression line would have the slope of a 45 degree line. In this extreme case, if the typical worker in a particular immigrant group earns 30 percent more than a third generation worker, the typical second generation descendant of that group would also earn 30 percent more than the third generation. There is no regression towards the mean because the ethnic differences stick completely from generation to generation.

Table 3 reports the estimated intergenerational correlations over both the 1940-70 period and the 1970-2000 period. Among working men, the intergenerational correlation reported in row 2 of the table is 0.511 for the $1940-1970$ period, and 0.560 for the $1970-2000$ period. Among working women (reported in row 3), the intergenerational correlations are smaller, 0.242 for the 
1940-1970 period and 0.280 for the 1970-2000 period. As noted above, however, the intergenerational changes in the relative wage of working women may reflect not only the transmission of skills but also the changes in the selection bias resulting from the dramatic increase in the female labor force participation rate over this six-decade period.

The bottom panel of Table 3 reports the estimated intergenerational correlations after the earnings data is adjusted not only for age differences across the groups, but for differences in educational attainment as well. The intergenerational correlations become much weaker after the data control for the differences in educational attainment. The intergenerational correlation estimated in the sample of working men, for example, drops by nearly half to 0.287 in the 19401970 period and to 0.245 in the $1970-2000$ period. In short, much of the stickiness in ethnic wage differentials arises because there is a significant transmission of differences in educational attainment across generations.

The estimated intergenerational correlations for working men reported in the top panel of the table suggest two important conclusions. First, the intergenerational correlation between the skills of the first and second generations is about halfway between zero and one. An intergenerational correlation of 0.5 implies that half of the wage differential between any two national origin groups in the first generation persists into the second generation. If the average wage of two ethnic groups is 30 percentage points apart in the first generation, the average wage of the two groups is expected to be about 15 percentage points apart in the second. There is some social mobility, therefore, but ethnicity remains an important determinant of labor market outcomes in the second generation.

Second, there is a remarkable stability in the estimates of the intergenerational correlation over the 1940-2000 period. The data clearly suggest that the process linking the economic 
performance of first and second generation national origin groups was quite similar during the last six decades of the $20^{\text {th }}$ century, despite the major changes in economic and social conditions, as well as in immigration policy, over the period. ${ }^{14}$

It is also important to determine if the ethnic differences that remain in the second generation get partially transmitted to the grandchildren of the immigrants. To establish how long a person's ethnic background matters in determining wage outcomes, one can track the economic performance of the grandchildren of the immigrants who entered during the "First" Great Migration at the beginning of the twentieth century. ${ }^{15}$ This tracking would use data from the 1910 Census to obtain information on the skill level of the national origin groups that made up the First Great Migration, and the General Social Surveys to obtain information on the sample of American-born workers (circa 1985) who had at least one grandparent born outside the United States.

Figure 2 summarizers some of the available data. There clearly exist differences in relative wages among third-generation ethnic groups — although these differences are far smaller than the ones observed in the first generation. Nevertheless, even after three-quarters of a century, there is a positive correlation between the relative wage of the original immigrant groups and the relative wage of the corresponding third-generation ethnic groups. The slope of the regression line linking the relative wage of the first generation and the relative wage of the

14 As noted in the previous section, the relation between the relative economic status of the first and second generations depends not only on the rate of regression towards the mean, but also on whether the second generation has a head start relative to the first generation. The intercept of the regression line illustrated in Figure 1 measures this intergenerational head start (i.e., the intercept measures the wage growth exhibited by the descendants of an immigrant group that had the same relative wage as the baseline third generation). The intercept (and standard error) is $0.107(0.021)$ in the 1940-1970 regression and $0.069(0.014)$ in the 1970-2000 regression.

15 George J. Borjas, "Long-Run Convergence of Ethnic Skill Differentials: The Children and Grandchildren of the Great Migration," Industrial and Labor Relations Review 47, no. 4 (1993): 553-573. 
third generation implies an intergenerational correlation of .22, so that 22 percent of the wage gap observed between any two groups in the immigrant generation persisted into the third.

Recall that roughly half of the wage gap between any two immigrant groups disappears between the first and second generations. It seems that about half of what remains in the second generation disappears between the second and the third. ${ }^{16}$

The historical record suggests one broad generalization. The "half-life" of ethnic skill differentials is roughly one generation — about half of the ethnic differences in relative wages disappears in each generation. Put differently, a 20-percentage point wage gap among ethnic groups in the immigrant generation implies a 10-point gap among second-generation groups, and a 5-point gap among third-generation groups.

\section{Ethnic Capital and Social Mobility}

The finding that the intergenerational correlation in the relative wage of ethnic groups is around 0.5 raises an important puzzle. Many studies conclude that about 20 to 40 percent of the skill differences among parents are typically transmitted to their children. ${ }^{17}$ It seems, therefore,

16 In a recent study, Richard Alba, Amy Lutz, and Elena Vesselinov question whether the correlation between the first and third generations illustrated in Figure 2 correctly portrays the experience of European immigrant groups. They show that it is easy to reduce the measured intergenerational correlation to nearly zero by selectively excluding particular ethnic groups from the analysis. In particular, they show that the statistical significance of the intergenerational correlation vanishes if the regression analysis drops Mexicans, Chinese, Japanese, Austrians, Hungarians, Poles, Yugoslavs, and Russian Jews from the sample. The wisdom of this selective pruning of the statistical evidence is highly questionable. The magnitude (and sign) of any statistical correlation can be changed at the researcher's whim by selectively screening the data; in this instance, by dropping observations of groups that do either too well or too poorly. See Richard D. Alba, Amy Lutz, and Elena Vesselinov, "How Enduring were the Inequalities among European Immigrant Groups in the U.S.?" Demography 38, no. 3 (2001): 349-356; and George J. Borjas, "Long-Run Convergence of Ethnic Skill Differentials, Revisited," Demography 38, no. 3 (2001): 357-361.

17 See Kenneth A. Couch and Thomas A. Dunn, "Intergenerational Correlations in Labor Market Status: A Comparison of the United States and Germany," Journal of Human Resources 32, no. 1 (1997): 210-232; Gary Solon, "Intergenerational Income Mobility in the United States," American Economic Review 82, no. 3 (1992): 393 - 
that there is more stickiness in the ethnic wage differential than one would expect simply from the intergenerational correlation between parents and children.

To solve this puzzle, it has been argued that a person's ethnic background-in and of itself - may influence the process of social mobility. ${ }^{18}$ In particular, the skills of the next generation depend not only on what parents do, but also on the characteristics of the ethnic environment where the children are raised — which has been called "ethnic capital." A highly advantaged ethnic environment—-where most parents are college graduates, for exampleimbues the children who grow up in that environment with valuable characteristics that enhance the children's socioeconomic achievement later in life. In contrast, disadvantaged ethnic environments - where most parents may be high school dropouts or welfare recipients —imbue the children raised in those environments with characteristics that may impede future socioeconomic achievement. In effect, the ethnic environment is like glue in the process of social mobility, ensuring that the average characteristics of the ethnic group do not change much from generation to generation.

To illustrate the link between ethnic capital and social mobility, consider the outcomes facing the children of a hypothetical Mexican and Korean family. Suppose the parents in these two families are similar in terms of the relevant socioeconomic characteristics. Even though the parents in these families are, say, high school graduates, the child in the Mexican household will likely grow up in an ethnic enclave where many of the neighbors are high school dropouts and where few of the child's friends go on to college. In contrast, the child in the Korean household

408; and David J. Zimmerman, "Regression toward Mediocrity in Economic Status," American Economic Review 82, no. 3 (1992): 409-429.

18 George J. Borjas, “Ethnic Capital and Intergenerational Mobility,” Quarterly Journal of Economics 107, no. 1 (1992): 123-150. 
will likely grow up in an area where many neighbors have some college education and where many of the child's friends will go on to college.

If ethnic capital matters - in other words, if exposure to different types of ethnic influences has an effect on social and economic development - the two children in this hypothetical example are on different socioeconomic paths, and these paths will lead to very different life experiences. The Mexican child will be continually exposed to the cultural and economic contacts that are common among low-educated workers, while the Korean child will be exposed to the contacts that are common among college graduates. The ethnic capital hypothesis argues that the continual exposure to a particular type of ethnic capital tends to "pull" the child towards the average or norm in that ethnic group. In other words, ethnic capital is like a magnet - attracting the child towards the socioeconomic outcomes experienced by the typical person in the particular ethnic group. In effect, ethnic capital increases the stickiness in ethnic wage differentials across generations.

A number of studies have shown that ethnicity seems to have an independent effectabove and beyond the information provided by parental socioeconomic outcomes - on the outcomes of children in particular ethnic groups, and that much of the ethnic capital effect can be directly linked to the importance of ethnic enclaves, which tend to cluster workers with relatively similar socioeconomic characteristics into a very compact geographic area. ${ }^{19}$ In rough terms, about half of the stickiness in the relative wage of different ethnic groups documented in the previous section seems to be attributable to the spillover effects associated with ethnic capital.

19 George J. Borjas, "Ethnicity, Neighborhoods, and Human Capital Externalities," American Economic Review 85, no. 3 (1995): 365-390. See also David M. Cutler, Edward L. Glaeser, and Jacob L. Vigdor, "Ghettos and the Transmission of Ethnic Capital," in Ethnicity, Social Mobility and Public Policy: Comparing the US and UK, edited by Glenn Loury, Tarig Modood, and Steven M. Teles (New York: Cambridge University Press, 2005), pp. 
It is worth stressing that the mix of factors that make ethnic capital a socially important construct may differ significantly across ethnic groups and across ethnic enclaves. A recent study of ethnic neighborhoods in Los Angeles documents that local social organizations and businesses in Chinatown and Koreatown are dominated by the respective ethnic group, while those in PicoUnion (a Mexican/Central American immigrant neighborhood) tend to be much more mixed. ${ }^{20}$ The Chinese and Korean owners of small businesses tend to attend local churches in their respective ethnic enclave, eat at local restaurants, and shop at local stores alongside the working class Chinese and Korean immigrants. Such mixing, however, is rarer in the Mexican/Central American neighborhood. Because the social and economic consequences of these different types of interactions are not fully understood, much work remains to be done in delineating how the concept of ethnic capital helps or hampers the assimilation process for different ethnic groups.

\section{Do Current Conditions Promote or Hinder Social Mobility for Immigrants?}

The evidence reported in this paper can be summarized in terms of two general insights.

First, the historical trend over much of the $20^{\text {th }}$ century suggests that the intergenerational "jump" in relative wages between the first and second generations is somewhere between 5 and 10 percentage points. If this historical trend were to continue into the future, the relatively low relative wage of the current immigrant workforce suggests that the next generation of second-

204-222; and Alexis Leon, "Does 'Ethnic Capital' Matter? Identifying Peer Effects in the Intergenerational Transmission of Ethnic Differentials," Working Paper (Pittsburgh, PA: University of Pittsburgh, 1995).

20 Min Zhou, "How Neighborhoods Matter for Immigrant Adolescents," CPRC Brief (Berkeley, CA: California Policy Research Center, December 2002); see also Min Zhou and Susan S. Kim, "Community Forces, Social Capital, and Educational Achievement: The Case of Supplementary Education in the Chinese and Korean Immigrant Communities," Harvard Educational Review, forthcoming 2006. 
generation workers, who will make up an important part of the workforce in 2030, may experience a sizable wage disadvantage of around 10 percent.

Second, the conclusion that ethnic skill differentials have a half-life of one generation has important implications for ethnic inequality throughout the next century. For example, Canadian immigrants earned 22.6 percent more than the baseline third generation, while Mexican immigrants earned 45.1 percent less. If the historical pattern were to hold, the third-generation descendants of today's Canadian immigrants will earn about 17 percent more than the descendants of today's Mexican immigrants towards the end of the $21^{\text {st }}$ century.

Note, however, that these glimpses into the crystal ball crucially rely on the assumption that the same forces that promoted (or hindered) social mobility in the past century continue indefinitely into the future. The available evidence clearly indicates that the intergenerational correlation for ethnic wage differences was around 0.5 for much of the $20^{\text {th }}$ century. But this rate of social mobility was shaped by unique historical events and by social and economic circumstances that may be difficult to replicate in the future.

For instance, the immigrants who entered the United States at the beginning of the $20^{\text {th }}$ century faced dramatically different economic conditions than the immigrant workforce today. In the early 1900s, the low-skill immigrant workforce helped build the manufacturing sector; threequarters of the workers at the Ford Motor Company in 1914 were foreign-born and over half of these immigrants came from the less developed areas of southern and eastern Europe. These manufacturing jobs evolved into stable and well-paying economic opportunities to many immigrants and their descendants. It is far from clear that the employment sectors seeking immigrants today—particularly in a labor market that increasingly rewards high-skill workers—- 
can provide the same growth opportunities that the rapidly expanding manufacturing sector offered to their counterparts a century ago.

Second, in some respects there is less ethnic diversity among the "new" immigration than there was among early $20^{\text {th }}$ century immigrants. In particular, current immigration is much more dominated by a single ethnic group than the First Great Migration ever was. In 2000, for example, Mexicans made up almost 30 percent of the immigrant population. In contrast, the largest two national origin populations enumerated by the 1920 Census were Germans and Italians, and together these two populations comprised only 24 percent of the foreign-born population at the time. The relative lack of ethnic diversity in post-1965 immigration may greatly reduce the incentives for assimilation by allowing the largest ethnic groups to essentially develop separate enclave economies and social structures, interacting little with the economic mainstream. These ethnic enclaves may well impede the assimilation process and create an additional obstacle in the road of social mobility.

Third, the political reaction to the social and economic dislocations associated with the First Great Migration was swift and severe. By 1924, the United States had adopted strict limitations on the number and types of persons who could enter the country. This policy shift, combined with the poor economic opportunities available during the Great Depression, created a de facto immigration moratorium. In the 1920s, 4.1 million persons entered the United States; by the 1930s, only half a million persons entered the country. This moratorium could have provided a "breathing period" that may have fueled immigrant social mobility by cutting off the supply of new workers to ethnic enclaves, and by reducing the economic and social contacts between the immigrants and the various countries of origin. 
Fourth, there is an important sense in which some of the large immigrant groups that arrived in the United States before 1924 were "encouraged" to assimilate by the changes in social attitudes and in tolerance towards particular national origin groups associated with the two World Wars. The Harvard Encyclopedia of American Ethnic Groups reports that "by summer 1918 about half of the [U.S.] states had restricted or eliminated German-language instruction, and several had curtailed freedom to speak German in public...The total number of German language publications declined from 554 in 1910 to 234 in 1920." ${ }^{21}$ Surely these unique and sudden shifts in social attitudes had a distinctive effect on the social mobility experienced by Germans and Italians in the United States.

Finally, the favorable ideological climate that boosted social pressures for assimilation and acculturation throughout much of the $20^{\text {th }}$ century has all but disappeared. Put differently, the consensus summarized by the motto of the United States seal, "E pluribus, Unum" (Out of many, one), no longer exists. The radical shift in the paradigm is best illustrated by Vice President Albert Gore's 1994 ruminations on the melting pot—and illuminating mistranslation of the motto: "We can build a collective civic space large enough for all our separate identities, that we can be E Pluribus Unum-out of one, many."

Because of these factors, the social mobility of the immigrants who arrived a century ago may not be a good predictor of the assimilation prospects of current immigrants. It is still too early to determine if these factors will prove important and slow down the rate of economic assimilation of the new immigrants. Nevertheless, the dramatic shifts in the social, political, and

21 Kathleen M. Conzen, "Germans" in Harvard Encyclopedia of American Ethnic Groups, edited by Stephen Thernstrom (Cambridge, Mass.: Harvard University Press, 1980), p. 423. 
economic climate suggest that ethnic differences could easily be incubated for much longer periods in the future. 
Figure 1. Social mobility between $1^{\text {st }}$ and $2^{\text {nd }}$ generations, $1970-2000$

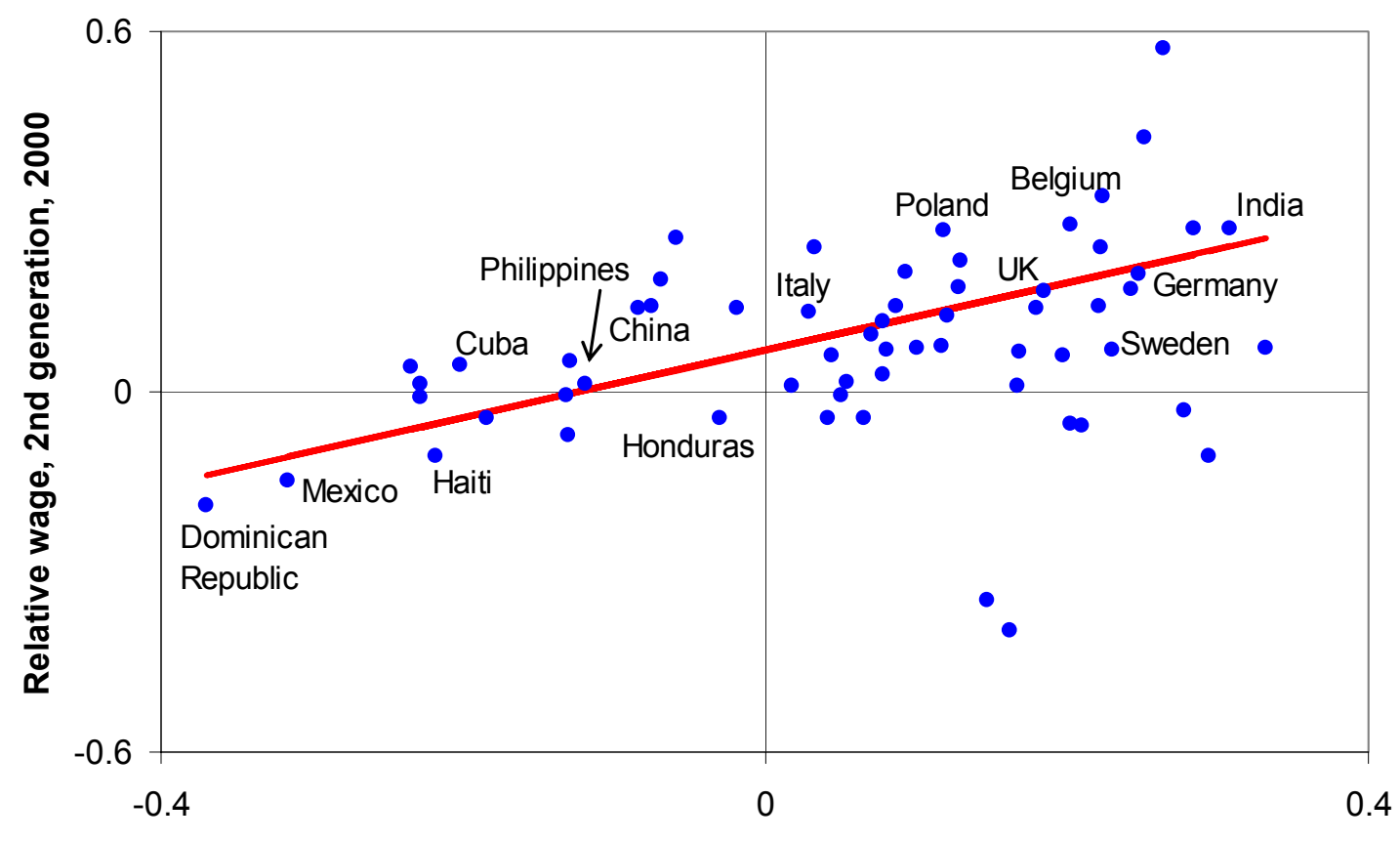

Relative wage, 1st generation, 1970

Source: Author's calculations from the 1970 Census and the pooled 1995-2003 March Current Population Surveys. The relative wage gives the age-adjusted log wage differential between a particular group and the typical thirdgeneration worker in the labor market at that point in time. 
Figure 2. Social mobility between $1^{\text {st }}$ and $3^{\text {rd }}$ generations, 1910 and 1985.

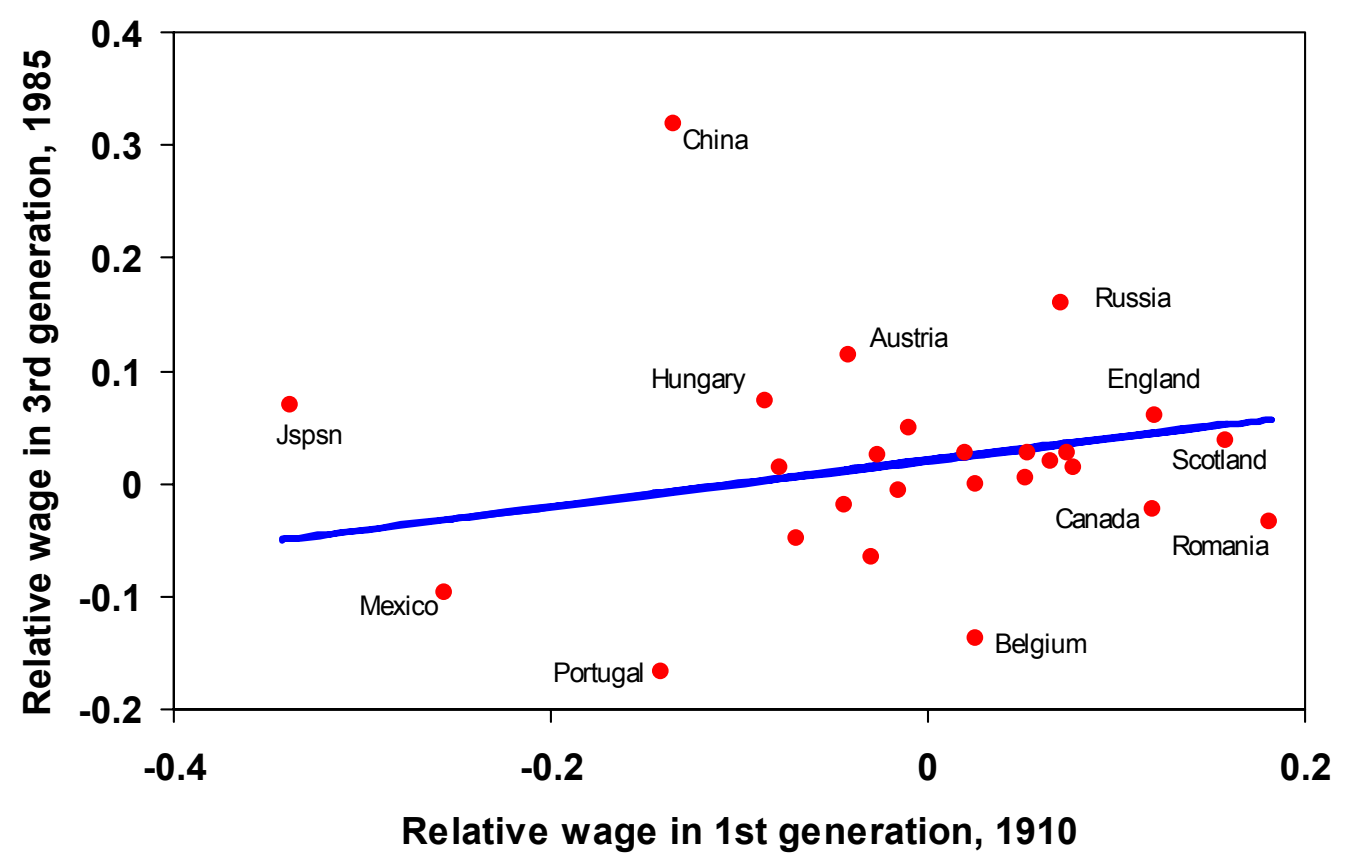

Source: George J. Borjas, "Long-Run Convergence of Ethnic Skills Differentials: The Children and Grandchildren of the Great Migration," Industrial and Labor Relations Review 47, no. 4 (July 1994), pp. 561-562. The relative wage gives the log wage differential between a particular group and the typical worker in the labor market at that point in time. 
Table 1. Wage differentials across generations

\begin{tabular}{lrrr} 
& 1940 & 1970 & 2000 \\
\cline { 2 - 4 } Age-adjusted log weekly wage, relative to $3^{\text {rd }}$ generation & & & \\
Male: & & & \\
$\quad 1^{\text {st }}$ generation & 0.058 & 0.014 & -0.197 \\
$2^{\text {nd }}$ generation & 0.178 & 0.146 & 0.063 \\
Female: & & & \\
$\quad 1^{\text {st }}$ generation & -0.007 & 0.068 & -0.102 \\
$2^{\text {nd }}$ generation & 0.115 & 0.101 & 0.088
\end{tabular}

Age- and education-adjusted log weekly wage, relative to

$3^{\text {rd }}$ generation

Male:

$1^{\text {st }}$ generation

$\begin{array}{lll}0.107 & 0.028 & -0.106\end{array}$

$2^{\text {nd }}$ generation

$\begin{array}{lll}0.189 & 0.124 & 0.029\end{array}$

Female:

$1^{\text {st }}$ generation

$\begin{array}{lll}0.106 & 0.101 & -0.034\end{array}$

$2^{\text {nd }}$ generation

$\begin{array}{lll}0.164 & 0.101 & 0.057\end{array}$

Source: Author's calculations from the 1940 and 1970 Censuses, and the pooled 1995-2003 March Current Population Surveys. 
Table 2. Age-adjusted relative wage for selected ethnic groups, 1970-2000 (relative to the third generation)

Country of origin:

Relative wage of immigrants in 1970
Relative wage of second generation in 2000
Canada

Cuba

Dominican Republic.

El Salvador

France

Germany

Greece

Haiti

India

Ireland

Italy

Jamaica

Mexico

Nicaragua

Norway

Philippines

Poland

Portugal

Spain

Switzerland

UK

$\begin{array}{rr}0.185 & 0.168 \\ -0.202 & 0.044\end{array}$

$-0.189$

$0.066-0.043$

$0.198 \quad 0.059$

$0.249 \quad 0.195$

$\begin{array}{ll}-0.019 & 0.139\end{array}$

$-0.217 \quad-0.106$

$\begin{array}{ll}0.308 & 0.271\end{array}$

$0.243 \quad 0.170$

$0.029 \quad 0.131$

$\begin{array}{lr}-0.228 & 0.012\end{array}$

$\begin{array}{ll}-0.316 & -0.147\end{array}$

$-0.184-0.043$

$0.278 \quad-0.032$

$-0.119 \quad 0.014$

$0.119 \quad 0.269$

$\begin{array}{ll}-0.234 & 0.042\end{array}$

$\begin{array}{ll}-0.074 & 0.141\end{array}$

$0.252 \quad 0.422$

$\begin{array}{ll}0.033 & 0.239\end{array}$

Source: Author's calculations from the 1970 Censuses, and the pooled 1995-2003 March Current Population Surveys. 
Table 3. Intergenerational correlation in relative wages

\section{Age-adjusted}

All workers

Male

Female

$1940-1970$

$1970-2000$

$\begin{array}{cc}0.416 & 0.434 \\ (0.113) & (0.089) \\ 0.511 & 0.560 \\ (0.127) & (0.066) \\ 0.242 & 0.280 \\ (0.091) & (0.123)\end{array}$

Age- and education-adjusted

$\begin{array}{lcc}\text { All workers } & 0.202 & 0.128 \\ \text { Male } & (0.088) & (0.022) \\ & 0.287 & 0.245 \\ \text { Female } & (0.101) & (0.034) \\ & 0.061 & -0.007 \\ & (0.070) & (0.042)\end{array}$

Notes: Author's calculations from the 1970 Censuses, and the pooled 1995-2003 March Current Population Surveys.

Standard errors are reported in parentheses. The regressions estimated in the 1940-1970 period use information from 30 national origin groups, while the regressions for the 1970-2000 period use information for 61 national origin groups The regressions are weighted by the size of the ethnic group in the second generation. 